American Journal of Pharmacology and Toxicology 4 (3):89-93, 2009

ISSN 1557-4962

(C) 2009 Science Publications

\title{
Anti-Ulcer (Ulcer-Preventive) Activity of Ficus arnottiana Miq. (Moraceae) Leaf Methanolic Extract
}

\author{
${ }^{1}$ Marslin Gregory, ${ }^{1}$ K.P. Vithalrao, ${ }^{2}$ G. Franklin and ${ }^{1}$ V. Kalaichelavan \\ ${ }^{1}$ Department of pharmacology, Annamalai University, Chidambaram, India \\ ${ }^{2}$ Centre for the Research and Technology of Agro-Environment and Biological Sciences (CITAB), \\ Department of Biology, University of Minho, Gualtar Campus, \\ 4710-057 Braga, Portugal
}

\begin{abstract}
Problem statement: In spite of being one of the well-known medicinal plants used in Indian traditional medicine to treat several ailments, studies pertaining to the pharmacological properties of Ficus arnottiana are very scarce. We studied the anti-ulcer activity and acute toxicity of Ficus arnottiana leaf methanolic extract for the first time. Approach: Freshly collected $F$. arnottiana leaves were dried, powdered and extracted in methanol. To study the anti-ulcer activity, Wistar rats were orally administered with different doses of the extract $\left(0,250\right.$ and $500 \mathrm{mg} \mathrm{kg}^{-1}$ body weight day $\left.^{-1}\right)$ or with the reference drug omeprazole $\left(8 \mathrm{mg} \mathrm{kg}^{-1}\right)$ for 10 days. After induction of ulcer using $5 \mathrm{~mL} \mathrm{~kg}^{-1}$ ethanol, stomachs of these animals were analyzed for gastric volume, ulcer area and gross pathological changes. Results: Our results showed that $F$. arnottiana methanolic extract could prevent ulcer in rats in a dose-dependent manner. Histological studies revealed that the extract had mucoprotective activity. The extract did not show any acute toxicity even at the dose of $5000 \mathrm{mg} \mathrm{kg}^{-1}$ indicating that the extract has no lethal effect. Preliminary phytochemical screening of this extract identified the presence of important secondary metabolites like flavonoids and tannins. Conclusion/Recommendations: From this study, it is clear that $F$. arnottiana leaf extract had significant anti-ulcer activity in animal models. It had muco-protective activity and gastric antisecretary activity. The extract is non-toxic even at relatively high concentrations.
\end{abstract}

Key words: Ficus arnottiana, flavonoids, gastric volume, ulcer area, omeprazole

\section{INTRODUCTION}

Ulcer is defined as the erosion in the lining of the stomach or duodenum and is caused by the disruptions of the gastric mucosal defense and repair systems ${ }^{11}$. Ulcer in the stomach is called gastric ulcer and in the duodenum is called duodenal ulcer and together peptic ulcer. In clinical practice, peptic ulcer is one of the most prevalent gastrointestinal disorders, commonly occurs in developed countries. Treatments available for ulcer is generally non-specific and is usually aimed at reducing the production of gastric acid and re-enforcing gastric mucosal protection such as regular food, adequate rest and avoidance of ulcerogenic agents such as coffee, alcohol and tobacco. The drugs used in the treatment of ulcer include receptor blockers, proton pump inhibitors, drugs affecting the mucosal barrier and act on the central nervous system $^{[2]}$. Even though a range of drugs are available for the treatment of ulcer, many of these do not fulfill all the requirements and have side effects ${ }^{[3-4]}$.
Recently, there has been much interest in natural medicines derived from the traditional knowledge of plant pharmacological properties. Large number of medicinal plants and dietary nutrients have been shown to posses gastro-protective activity ${ }^{[5-9]}$.

Ficus arnottiana miq. (Moraceae) is an important traditional medicinal plant distributed throughout India, mostly in rocky hills of $1,350 \mathrm{~m}$ elevations ${ }^{[10]}$. It has several vernacular names including paras pipal and kodiarasu. The fruits of the plant contain $\beta$ sitosterol, gluanol acetate and glucose, friedelin ${ }^{[11]}$. Sterols, alkaloids, carbohydrates, tannins, phenols etc are present in the bark extracts ${ }^{[12]}$. Bark and leaf extract of this plant is being used in the traditional medicine. Bark of the plant is used as astringent, aphrodisiac, demulcent, depurative and emollient. It is also useful against inflammation, diarrhoea, diabetes, burning sensation, leprosy, scabies, wounds and skin diseases ${ }^{[13]}$.

In spite of being one of the well-known medicinal plants used in Indian traditional medicine, studies

Corresponding Author: G. Franklin, CITAB, Department of Biology, University of Minho, Gualtar Campus, 4710-057 Braga, Portugal Tel: +351 253604317/18 Fax: +351 53678980 
pertaining to the pharmacological properties of $F$. arnottiana are very scarce. In this context, hypoglycemic and antioxidant effect of an isolated compound (Ficanone) from $F$. arnottiana bark has been reported recently ${ }^{[12]}$. Although other species of this genus has been reported for anti-ulcer activity ${ }^{[9]}$, $F$. arnottiana has so far not been screened for anti-ulcer activity. Hence, we studied the anti-ulcer (ulcerpreventive) activity and acute toxicological effects of $F$. arnottiana methanolic extract in the present investigation.

\section{MATERIALS AND METHODS}

Chemicals and reference drug: All chemicals used in the present study were analytical grade and purchased from SD fine chemicals Ltd (Mumbai, India). Omeprazole (reference drug) was a gift from Dr. Reddy's laboratories (Hyderabad, India). Omeprazole blocks the enzymes in the wall of the stomach from producing acid. By blocking the enzyme, the production of stomach acid is decreased, thus allowing the stomach to heal ${ }^{[9]}$.

Plant material and extract preparation: F. arnottiana plants were identified taxonomically and authenticated by Mr. Sukumar, a botanist from the Department of botany, Annamalai University. Fresh leaves were collected, dried under shade, powdered and stored in an airtight container. $F$. arnottiana leaf powder $(250 \mathrm{~g})$ was loosely packed in the thimble of soxhlet apparatus and extracted with methanol at $55^{\circ} \mathrm{C}$ for $18 \mathrm{~h}$. The extract was air dried at $25-30^{\circ} \mathrm{C}$ and weighed. For oral administration, extract was dissolved in $10 \mathrm{~mL}$ Phosphate Buffer Saline (PBS) at different concentrations. To make the extract soluble in PBS, $1 \%$ tween 80 was used.

Phytochemical screening: The freshly prepared crude methanolic extract of $F$. arnottiana was qualitatively tested for the presence of major phytochemical constituents using the methods summarized in the following Table 1.

Table 1: Methods used for the qualitative identification of major group of compounds

\begin{tabular}{ll}
\hline Phytochemicals tested & Test method \\
\hline Alkaloids & $\begin{array}{l}\text { Dragendorff's, Mayer's and Wagner's } \\
\text { reagent }{ }^{[14]}\end{array}$ \\
Flavonoids & $\begin{array}{l}\text { Shinoda test } \\
{ }^{[15]}\end{array}$ \\
Tannins & $\begin{array}{l}\text { Ferric chloride and potassium dichromate } \\
\text { solutions }\end{array}$ \\
Steroids & Salkovaski test \\
Corbohydrate & Molish and Barfoed's test ${ }^{[17]}$ \\
Amino acids & Ninhydrine test ${ }^{[17]}$ \\
\hline
\end{tabular}

Animals: Wistar rats (180-200 g) and male albino mice $(20-25 \mathrm{~g})$ were obtained from the Central animal house, Annamalai University and kept in standard environmental conditions. They were fed with rodent diet and water ad libitum. Experiments were carried out in accordance with CPCSEA guidelines and the study was approved by Institutional animal ethical committee.

Acute toxicity study: Five groups $(n=5)$ of male albino mice were used in the acute toxicity study of $F$. arnottiana methanolic extract. Animals from all groups were fasted overnight and administered (p.o) with single dose $\left(250,500,2000\right.$ and $\left.5000 \mathrm{mg} \mathrm{kg}^{-1}\right)$ of the extract. A group of animals which received equal volume of PBS served as control. Changes in the behavior of animals were observed for $24 \mathrm{~h}$ after extract administration. For any signs of toxicity and mortality, animals were observed for 14 days.

Anti-ulcer (ulcer-preventive) activity study: Five groups $(n=6)$ of Wistar rats were used to study the anti-ulcer activity of $F$. arnottiana methanolic extract. PBS, methanolic extract, omeprazole and ethanol were administered to the animals per orally (p.o). Group 1 received PBS (10 $\mathrm{mL} \mathrm{kg}^{-1}$ ) all over the experimental period (11 days) and served as control. Group 2 received PBS $\left(10 \mathrm{~mL} \mathrm{~kg}^{-1}\right)$ for 10 days and on the 11th day received absolute ethanol $\left(5 \mathrm{~mL} \mathrm{~kg}^{-1}\right)$ and served as ulcer control. Group 3 and 4 were respectively administered with 250 and $500 \mathrm{mg} \mathrm{kg}^{-1} F$. arnottiana methanolic extract, group 5 with omeprazole $\left(8 \mathrm{mg} \mathrm{kg}^{-1}\right)$ for 10 days. All the groups were fasted for $24 \mathrm{~h}$ and again administered with the extract or drug at respective dose. After $30 \mathrm{~min}$ of this treatment, animals of groups 2-5 were administered with $5 \mathrm{~mL} \mathrm{~kg}^{-1}$ ethanol to induce ulcer. After $15 \mathrm{~min}$ of ethanol administration, all the animals were sacrificed using anaesthetic ether. Gastric volume was measured by pylorus ligation method $^{[18]}$. Each stomach was opened along the greater curvature and examined macroscopically for gastric erosions under a dissecting microscope $(20 \mathrm{X})$. The length and width $(\mathrm{mm})$ of ulcer on the gastric mucosa were measured by plane glass square $(10 \times 10 \mathrm{~mm})$. The Ulcer Area (UA) was calculated. The $\%$ of protection (P\%) availed to the animals through various treatments was calculated using the formula:
$\mathrm{P} \%=(\mathrm{UA}$ ulcer control-UA treatment $) / \mathrm{UA}$ ulcer control $\times 100$

Histopathology: After collecting the gastric contents and measuring the ulcer area, small pieces of stomachs 
from each group were embedded in paraffin wax. Sections of $5 \mu \mathrm{m}$ thick were cut in a microtome and mounted on glass slides using standard techniques. After staining the tissues with hematoxylin-eosin stain, the slides were viewed under a light microscope equipped for photography.

\section{RESULTS}

Phytochemical screening: Phytochemical analyses of the methanolic extract of $F$. arnottiana leaves revealed the presence of flavonoids, tannins, carbohydrates and proteins.

Anti-ulcer (ulcer-preventive) activity study: As seen in the Table 2, pretreatment of rats with $F$. arnottiana leaf methanolic extract rendered a dose-dependent protection from ethanol-induced ulceration. When compared to the ulcer control animals, extract treatment provided more or less 30 and $63 \%$ protection respectively at 250 and $500 \mathrm{mg} \mathrm{kg}^{-1}$ doses. Although omeprazole, the reference drug used in the study at $8 \mathrm{mg} \mathrm{kg}^{-1}$ dose provided the animals with the highest ulcer protection (78\%), the effect of $500 \mathrm{mg} \mathrm{kg}^{-1}$ dose of extract was comparable (63\%) with the reference drug.

Gross pathological studies of the stomachs removed from animals that were not pre-treated with either omeprazole or $F$. arnottiana showed complete ulceration (Fig. 1a). However, a preventive effect against ulceration (in terms of ulcer area) was noticed in animals pretreated with omeprazole (Fig. 1b) and $500 \mathrm{mg} \mathrm{kg}^{-1}$ methanolic extract of $F$. arnottiana (Fig. 1c).

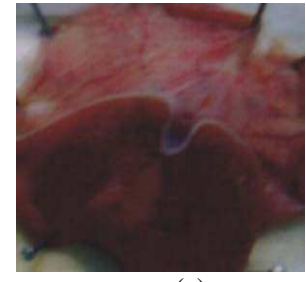

(a)

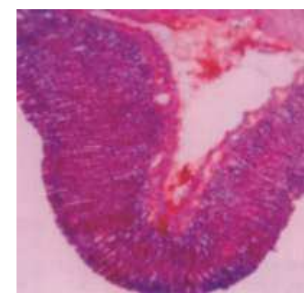

(d)

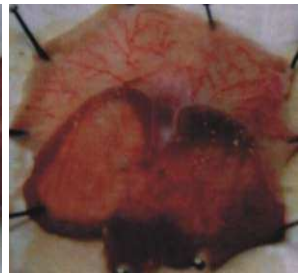

(b)

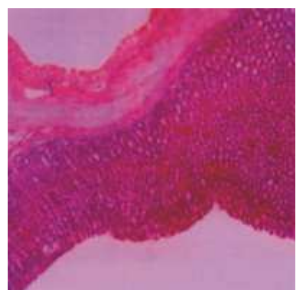

(e)

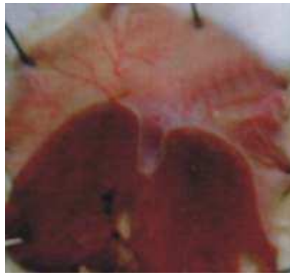

(c)

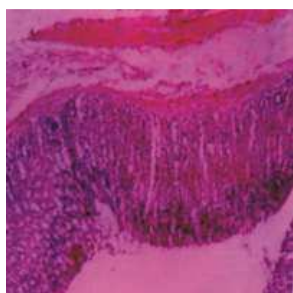

(f)

Fig. 1: Anti-ulcer activity of methanolic extract obtained from F. arnottiana leaves. (a): Stomach of an ulcer control rat; (b): Stomach of a rat treated with $8 \mathrm{mg} \mathrm{kg}^{-1}$ omeprazole; (c): Stomach of a rat treated with $500 \mathrm{mg} \mathrm{kg}^{-1}$ $F$. arnottiana leaf methanolic extract. Respective histopathological sections are shown down; (d): Stomach of the ulcer control animal showing mucosa with hemorrhagic erosion, discontinuity in the lining of epithelium cells and significant damage to sub-mucosa; (e): Stomach of omeprazole treated animals showing normal mucosa with small strophic gland mild hyperplasia and no edema; (f): Stomach of animals administered with $500 \mathrm{mg} \mathrm{kg}^{-1} F$. arnottiana leaf methanolic extract showing normal mucosa with mild hyperplasia and mild edematous sub-mucosa

Table 2: Anti-ulcer activity of $F$. arnottiana leaf methanolic extract

\begin{tabular}{lllll}
\hline Treatment & Dose $\left(\mathrm{mg} \mathrm{kg}^{-1}\right)$ & Gastric volume $(\mathrm{mL})$ & Ulcer area $\left(\mathrm{mm}^{2}\right)$ & Protection $(\%)$ \\
\hline Control & NA & $0.80 \pm 0.04 \mathrm{a}$ & $0.00 \pm 0.0 \mathrm{a}$ & NA \\
Ulcer control & 0 & $2.96 \pm 0.26 \mathrm{c}$ & $890.66 \pm 9.66 \mathrm{e}$ & 0.0 \\
Drug control (Omeprazole) & 8 & $1.97 \pm 0.22 \mathrm{~b}^{*}$ & $193.33 \pm 12.50 \mathrm{~b}^{*}$ & $78.29 \%$ \\
Treatment 1 (F. arnottiana) & 250 & $2.56 \pm 0.26 \mathrm{c}$ & $618.33 \pm 11.00 \mathrm{~d}^{*}$ & $30.57 \%$ \\
Treatment 2 (F. arnottiana) & 500 & $1.86 \pm 0.27 \mathrm{~b}^{*}$ & $331.67 \pm 27.86 \mathrm{c}^{*}$ & $62.76 \%$ \\
\hline
\end{tabular}

Values are expressed as mean \pm SE. Data were analyzed using One way ANOVA followed by Tukey's multiple comparison test). Values in a column followed by different letters are significantly different $(\mathrm{p}<0.001)$.Values in a column with an asterix $(*)$ are significantly different from the ulcer control $(\mathrm{p}<0.001)$ 
Am. J. Pharm. \& Toxicol., 4 (3):89-93, 2009

Table 3: Changes in the animal behavior after administration of $F$. arnottiana methanolic extract $5000 \mathrm{mg} \mathrm{kg}^{-1}$ dose

\begin{tabular}{lcccccc}
\hline \multicolumn{7}{c}{ Time after administration (h) } \\
\hline Gross activity & 2 & 3 & 5 & 7 & 12 & 24 \\
Respiration & - & - & - & - & - & - \\
Writhing & - & - & - & - & - & - \\
Tremors & - & - & - & - & - & - \\
Convulsion & - & - & - & - & - & - \\
Salivation & - & - & - & - & - & - \\
Diarrhoea & - & - & - & - & - & - \\
Mortality & - & - & - & - & - & - \\
Hind limb paralysis & - & - & - & - & - & - \\
Sedation & + & - & - & - & - & - \\
Skin irritation & + & - & - & - & - & - \\
Eye irritation & - & - & - & - & - & - \\
CNS Depression & + & + & - & - & - & - \\
\hline +: Indicates that change \\
change
\end{tabular}

Histopathology of stomach show that animals that have received $500 \mathrm{mg} \mathrm{kg}^{-1}$ extract significantly reduced gastric lesion formation and sub-mucosal edema similar to the omeprazole treated animals. Careful evaluation of the photomicrographs revealed that the mucosa of ulcer control animals have hemorrhagic erosion, discontinuity in the lining of epithelium cells and significant damage in sub-mucosa (Fig. 1d). Normal mucosa with small strophic gland, mild hyperplasia and no edema were observed for animals treated with omeprazole (Fig. 1e). Similarly, mucosa of animals treated with $500 \mathrm{mg} \mathrm{kg}^{-1}$ $F$. arnottiana methanolic extract was normal with mild hyperplasia (Fig. 1f). However, slightly edematous sub mucosa was noticed in the latter.

Acute toxicity study: Single dose (250, 500, 2000 and $5000 \mathrm{mg} \mathrm{kg}^{-1}$ ) of $F$. arnottiana leaf methanolic extract administered to albino mice showed no death up to 14 days study period (data not shown). Even at the highest dose $\left(5000 \mathrm{mg} \mathrm{kg}^{-1}\right)$, there were no physical sings of toxicity as evidenced by normal breathing and the absence of tremors, convulsions, diarrhoeas, salivation and paralysis in the treated animals (Table 3). But CNS depression, skin irritation, sedation were noticed up to $3 \mathrm{~h}$ after administration of $5000 \mathrm{mg} \mathrm{kg}^{-1}$ extract. These observations reveal that the oral $\mathrm{LD}_{50}$ of methanolic leaf extract of $F$. arnottiana is greater than $5000 \mathrm{mg} \mathrm{kg}^{-1}$ in mice. Observation of animals over the next 14 days showed no adverse effect of treatment.

\section{DISCUSSION}

Ulcer has long been recognized as one of the most important gastrointestinal problem. With the ever growing interest in natural medicine, many plants have been screened and reported to be useful in treating and managing ulcer. $F$. arnottiana have several pharmacological properties including anti-inflammatory and anti-diarrhoeal ${ }^{[13]}$. In spite of its uses in the traditional medicine against various ailments, this plant has so far not been screened for anti-ulcer activity. We report on the anti-ulcer activity of $F$. arnottiana leaf methanolic extract for the first time here.

The results of the present study have shown that $F$. arnottiana leaf methanolic extract possess gastroprotective activity, as evidenced by its significant inhibition in the formation of ulcers induced by ethanol (Table 2). The protective effect was confirmed by histological examination showing prevention of mucosal lesions and sub-mucosal edema. As flavonoids have been identified in the methanolic extract, we believe that the anti-ulcer activity of this extract is probably due to the antioxidant activity of the extract. Antioxidant activities of flavonoids have been well documented in the literature. Moreover, flavonoids have been reported for their anti-ulcerogenic activity and gastric protection already ${ }^{[19,20]}$.

Sub-acute toxicological studies have revealed that the methanolic extract of $F$. arnottiana show slight CNS depression for a few hours after treatment at the dose of $5000 \mathrm{mg} \mathrm{kg}^{-1}$ (Table 3). However, there was no sign of toxicity or mortality up to 14 days indicates that the extract is relatively safe. Any substance that is not toxic at $5000 \mathrm{mg} \mathrm{kg}^{-1}$ is considered relatively safe ${ }^{[21]}$.

\section{CONCLUSION}

From this study, it is clear that $F$. arnottiana leaf extract have significant anti-ulcer activity in animal models. It has muco-protective activity and gastric antisecretary when compared with that of reference drug omeprazole. The extract is non-toxic even at relatively high concentrations. The anti-ulcer activity is probably due to the presence of flavanoids. Further studies are being carried out to characterize and explore the biological activity of the compounds present in the extract.

\section{ACKNOWLEDGEMENT}

We would like to thank Central animal house and Animal ethical committee, Annamalai University for their help during the experiments.

\section{REFERENCES}

1. Grossman, M.I., 1981. Peptic Ulcer: A Guide for the Practicing Physician. Year Book Medical Publishers, Chicago, ISBN: 0815140096, pp: 179. 
2. Manonmani, S., V.P. Viswanathan, S. Subramanian and S. Govindasamy, 1995. Biochemical studies on the antiulcerogenic activity of cauvery 100, an ayurvedic formulation in experimental ulcers. Ind. J. Pharmacol., 27: 101-105. http://medind.nic.in/imvw/imvw15225.html

3. Anoop, A. and M. Jegadeesan, 2003. Biochemical studies on the anti-ulcerogenic potential of Hemidesmus indicus R. Br. Var. indicus. J. Ethnopharmacol., 84: 149-156. DOI: 10.1016/S0378-8741(02)00291-X

4. Dharmani, P., P.K., Mishra, R. Maurya, V.S. Chauhan and G. Palit, 2005. Allophylus serratus: A plant with potential anti-ulcerogenic activity. J. Ethnopharmacol., $\quad$ 99: 361-366. http://www.ncbi.nlm.nih.gov/pubmed/15878649

5. Borrelli, F. and A.A. Izzo, 2000. The plant kingdom as a source of anti-ulcer remedies. Phytother. Res., 14: 581-591. DOI: 10.1002/10991573(200012)14:8<581::AID-PTR776>3.0.CO;2-S

6. Dharmani, P. and G. Palit, 2006. Exploring Indian medicinal plants for antiulcer activity. Indian $\mathrm{J}$. Pharmacol., 35: 95-99. http://medind.nic.in/ibi/t06/i2/ibit06i2p95.pdf

7. Kath, R.K. and R.K. Gupta, 2006. Antoxidant activity of hydroalcoholic leaf extract of Ocimum sanctum in animal models of peptic ulcer. Ind. J. Physiol. Pharmacol., 50: 391-396. http://www.ncbi.nlm.nih.gov/pubmed/17402269

8. Malairajan, P., G. Gopalakrishnan, S. Narasimhan, K.J. Veni and S. Kavimani, 2007. Anti-ulcer activity of crude alcoholic extract of Toona ciliata Roemer (Heartwood). J. Ethnopharmacol., 110: 348-351. DOI: $10.1016 /$ j.jep.2006.10.018

9. Siti Fatimah Zahra, M.A., A.A. Mahmood, M.A. Hapipah, M.N. Suzita and I. Salmah, 2009. Anti-ulcerogenic activity of aqeous extract of Ficus deltoidea against ethanol-induced gastric mucosal injury in rats. Res. J. Med. Sci., 3: 42-46. http://medwelljournals.com/fulltext/rjms/2009/4246.pdf

10. Warrier, P.K., V.P.K. Nambiar and C. Ramankutty, 1994. Indian Medicinal Plants: A Compendium of 500 Species. Orient Longman Publisher, ISBN: 8125003029, pp: 423.

11. Chopra, R.N., S.L. Nayar and I.C. Chopra, 1996. Glossary of Indian Medicinal Plants. CSIR, New Dehli, ISBN: 8172361262.
12. Mazumder, P.M., M. Farswan, V. Parcha and V. Singh, 2008. Hypoglycemic and antioxidant activity of an isolated compound from Ficus arnottiana bark. Pharmacologyonline, 3: 509-519. http://www.unisa.it/download/1966_10305_18347 40342_49_Mitra.pdf

13. Pushparay, P., C.H. Tan and B.K.H. Tan, 2000. Effects of Averrhoea bilimbi leaf extract on blood glucose and lipid in STZ-diabetic rats. J. Ethanopharmacol., 72: 69-76. DOI: 10.1016/S0378-8741(00)00200-2

14. Kokate, C.K., A.P. Purohit and S.B. Gokhale, 2007. Pharmacognosy. 13th Edn., Nirali Prakashan Publisher, ISBN: 8185790094, pp: 635.

15. Ravishankara, M.N., N. Shrivastava, H. Padh and M. Rajani, 2002. Evaluation of antioxidant properties of root bark of Hemidesmus indicus R. Br. (Anantmul). Phytomedicine, 9: 153-160. http://www.ncbi.nlm.nih.gov/pubmed/11995949

16. Ganesan, A., S. Natesan, P.G. Perumal, R. Vellayutham, K. Manickam and N. Ramasamy, 2008. Anxiolytic, antidepressant and anti-Inflammatory activities of methanol extract of Momordica charantia Linn Leaves (Cucurbitaceae). Iran. J. Pharmacol. Therapeut., 7: 43-47. http://ijpt.iums.ac.ir/index.php/ijpt/article/viewFile/ 217/319

17. Satyanarayana, U., 1999. Biochemistry. 1st Edn., New Central Book Agency (P) Ltd., ISBN: 8187134801.

18. Kurasawa, T., Y. Chikaraishi, A. Naito, Y. Toyoda and Y. Notsu, 2005. Effect of Humulus lupulus on gastric secretion in a rat pylorus-ligated model. Biol. Pharm. Bull., 28: 353-357. DOI: 10.1248/bpb.28.353

19. Alarcón de la Lastra, C., M.J. Martin and V. Motilva, 1994. Antiulcerogenicity of the flavonoid fraction from Bidens aurea: Comparison with ranitidine and omeprazole. J. Ethnopharmacol., 42: 161-168. DOI: 10.1016/0378-8741(94)90081-7

20. Parmar, N.S. and S. Parmar, 1998. Anti-ulcer potential of flavonoids. Ind. J. Physiol. Pharmacol., 48: 343-351. http://www.ncbi.nlm.nih.gov/pubmed/974164821

21. Lorke, D., 1983. A new approach to practical acute toxicity testing. Arch. Toxicol., 54: 275-287. DOI: 10.1007/BF01234480 